Nordisk Tidsskrift for Kriminalvidenskab 2009

\title{
HVITVASKINGSREGULERINGENS KOSTNADER"
}

Av professor Paul Larsson og professor Dan Magnusson

The aim of this study is to estimate the costs of implementing anti-money laundering regulations in Norway and Sweden. The banks are the central institutions in this respect and the study shows that the annual costs of these regulations are approximately 400 million SEK in Sweden and 200 NOK in Norway. It is difficult to estimate the effects of anti-money laundering regulations upon the magnitude of money laundering itself. There is little evidence that these regulations have had any noteworthy preventive effect upon either the original criminality that gives rise to illegal earnings or the illegal endeavours, e.g., terrorism, to which these earnings are sometimes applied. It is, however, possible that the regulations strengthen the security and integrity of the financial institutions themselves. The use of intelligence in connection with investigations of financial crimes and other types of criminality can be seen as another positive outcome. There are also nonfinancial costs associated with these anti-money laundering regulations. The loss of secrecy in the banks and the increase of supervision within one more area of private life can be seen as the most serious. The regulations can also have unintended costs by contributing to the marginalization of vulnerable groups of bank customers. The article ends with some suggestions for reforms that may be helpful as a basis for a more precise cost/benefit evaluation of anti-money laundering regulations."

\section{Bakgrunnen for undersøkelsens}

De seneste tiår har utviklingen innen reguleringen rettet mot hvitvasking økt dramatisk ikke bare i vestlige land, men globalt. I løpet av relativt kort tid er det etablert et omfattende reguleringsregime for å overvåke, rapportere, etterforske og rettsforfølge noen typer transaksjoner som betegnes som hvitvasking. Noe av det særegne ved hvitvaskingsreguleringen er at det i utgangspunktet ikke var disse handlingene, vasken, i seg selv, som var målet for overvåkningen, men bakenforliggende lovbrudd. Ved å forsøke å ta pengene ville man knekke kriminaliteten.

Regelverket og kontrollen som har blitt innført er omfattende. Overvåkningsoppgavene er i overveiende grad lagt på private finansaktører som banker, forsikringsselskaper og verdipapirforetak for å nevne noen av de mest sentrale. Blant disse er det bankene som så langt har vært mest sentrale.

\footnotetext{
- Artikkelen er en omarbeidet versjon av en rapport levert i oktober 2008 til Nordisk Samarbeidsråd for Kriminologi. Takk til rådet for finansiering og økonomisk støtte til å gjennomføre undersøkelsen. Stor takk også til Karsten Ingvaldsen og Jan Georg Christophersen som var involvert tidlig i undersøkelsen og som har kommet med mange gode innspill.

"* Title in English: The Costs of Money Laundering Regulation. Original in Norwegian.
} 
Reguleringen av hvitvasking er på ingen måte et felt hvor de nordiske land har vært pionerer. Lover og regelverk som har styrt utviklingen og blitt implementert $i$ de nordiske lands lovgiving er internasjonal. Blant den mest sentrale lovgivingen internasjonalt har FNs narkotikakonvensjon fra 1988, Europarådets konvensjon om hvitvasking og beslag fra 1990 og det omfattende regelverket som siden har blitt utviklet innen EU vært. USA har likevel sammen med organisasjoner som FATF $^{1}$ vært minst like viktige for den globale utviklingen innen reguleringen (se figur 1). Det internasjonale trykket har vært av en slik art at det i liten grad har oppstått prinsipielle grunnleggende debatter om metodene, deres bakgrunn og siktemål i de nordiske land.

Flere har etter hvert begynt å stille spørsmål ved ulike sider ved reguleringen. Nederlenderen Petrus van Duyne har i en rekke arbeider behandlet problemstillingene hva vi vet om den illegale økonomien, hvordan svarte penger håndteres og behovet for hvitvasking (Duyne 2003, Duyne og Levi 2005). Andre har satt søkelys på effektene av reguleringen, men også kostnadene (Levi 2003, Reuter og Truman 2004, Rider 2004, Larsson 2008b). Man spør; hva kommer ut av det etter hvert svært så omfattende reguleringsregimet?

Effektene har vist seg vankelig å dokumentere. Vi vet ikke i hvilken grad reguleringen har virket kriminalitetsforebyggende fordi det knapt finnes noen kunnskap om hvor mye midler fra illegal virksomhet som vaskes. Man har heller ikke visst hva reguleringen har kostet. Kostnadene er av ulik art, det er ikke bare økonomiske utgifter som følger i reguleringens kjølvann, men også samfunnsmessige som er vanskelige å måle.

Det er gjort lite forskning på kostnadene og nytten av hvitvaskingsreguleringen så langt. Denne undersøkelsen må ses som et forsøk på å kartlegge noen av disse svarte hull. Dens siktemål i utgangspunktet var ganske ambisiøst, å kartlegge de totale kostnadene ved reguleringen i Sverige og Norge. Det viste seg at denne målsetningen var for bred, det bød på omfattende problemer å gjennomføre en undersøkelse av alle kostnadene. Undersøkelsen kom til å se bort fra de offentlige utgiftene. Noen av de offentlige utgiftene, knyttet opp mot Kredittilsynet og Økokrim, i Sverige Finansinspeksjonen og Finanspolisen, er relativt enkle å dokumentere. De totale kostnadene fordelt på etterforskning i politiet, bruk av etterretningsinformasjon og domstolsbehandling i praksis viser seg derimot vanskelig å skille ut fra annen virksomhet.

Bankene er de institusjonene som har stått og står mest sentralt og som er spydspissen innen reguleringen av hvitvasking. De har blitt pålagt størst ansvar med overvåkning og har tatt oppgavene mest seriøst. Bankene sender inn flest meldinger til statlige kontrollmyndigheter som følges opp med etterforskning. Vi har derfor konsentrert oss om bankenes kostnader, som uten sammenligning er de største innen den private sektor. 


\section{Hva er hvitvasking?}

I "gamle dager" siktet man med hvitvasking, money laundering, til en prosess som gjorde at penger tjent ved illegal virksomhet fremstod som ervervet gjennom legal virksomhet. Slik skiftet pengene antatt kulør, fra svarte eller skitne til hvite. Når amerikanske myndigheter begynte å behandle dette som en problemstilling på 1970 og 80 - tallet så ble reguleringen i sær solgt inn som et tiltak mot penger generert ved narkotikakriminalitet (Naylor 2002, Unger 2006). Første lovgiving mot hvitvasking kom i USA i 1986, etter FNs narkotikakonvensjon 1988 spredte reguleringen seg raskt internasjonalt. Selve begrepet hvitvasking - money laundering - er amerikansk og påstås å ha sin opprinnelse på 1920 tallet når organiserte kriminelle grupper plasserte sitt overskudd i bedrifter i typiske kontantbransjer. Mest populært var visstnok vaskerier og bilvasker (UN ODCCP 1998).

Å gå etter pengene ble introdusert som en preventiv metode for politiet. Man ønsket å stoppe eller redusere vasken gjennom banker og andre finansinstitusjoner og beslaglegge midlene som ble generert. Tanken bak er enkel. Ved å ta verdiene skapt ved lovbrudd ville man fjerne motivasjonen for kriminaliteten, redusere skadene man antok oppstod ved at kriminelle penger blandet seg i den legale økonomien og fjerne kapital som trengs for å utøve kriminalitet. Denne tenkemåten går som hånd $\mathrm{i}$ handske med rådende situasjonelle måter å forstå kriminalitet som resultat av rasjonelle handlingsvalg (Garland 2001). I god neoliberalistisk ånd har dessuten myndighetene i mange land sett fordelene ved at beslaglagte verdier tilfalt og til en viss grad finansierte politi og rettsvesen.

Hvitvaskingsbegrepet har utvidet seg betraktelig i løpet av kort tid. "Med hvitvasking av penger menes vanligvis å sikre utbyttet av en straffbar handling. Uttrykket hvitvasking inkluderer også det å motta eller å skaffe seg eller andre del i utbyttet av en straffbar handling." (Finansdepartementet 2002: 6)

I dag snakkes det lite om lovbruddene som pengene stammer fra, det som kalles primærforbrytelsen, i stedet har man blitt mer opptatt av håndteringen av pengene.

Listen over hva som dekkes av begrepet hvitvasking har blitt lang og ganske omstendelig. Definisjonen i EUs tredje hvitvaskingsdirektiv kan ta pusten fra den beste. Det er tydelig at kjernen i hvitvaskingsbegrepet $\mathrm{i}$ dag handler om ulike måter å forvalte eller håndtere penger som stammer fra lovbrudd. For enkelthets skyld referer vi her den danske kortversjonen av dette:

"Ved hvidvask skal i denne lov forstås

1. Uberettiget at modtage eller skaffe sig eller andre del i økonomisk udbytte, der er opnåed ved en strafbar lovovertrædelse,

2. uberettiget at skjule, opbevare, transportere, hjælpe til afhændelse eller på anden måde efterfølgende virke til at sikre det økonomiske udbytte fra en strafbar lovovertrædelse eller 
3. forsøge på eller medvirke til sådanne dispositioner.

Stk. 2. Bestemmelsen i stk. 1 omfatter også dispositioner foretaget af den, der har begået den strafbare lovovertrædelse, som udbyttet hidrører fra." (NOU $2007 \mathrm{nr}$ 10: 15)

Akademisk sett er hvitvaskingsbegrepet så utvannet at det er lite brukbart som operasjonelt vitenskapelig begrep. På den annen side kan det hevdes at dette i seg selv er et gode. Det gjør begrepet nyttig for de som skal bruke det i praksis fordi innholdet lett kan utvides til å inkludere høyst ulike problemer som ønskes bekjempet. Hvitvaskingsbegrepet åpner for å iverksette en rekke tiltak, blant annet informasjonsutveksling finansinstitusjoner imellom og opp mot kontrollmyndighetene man ellers ikke har rett til. Det gir reguleringsmyndighetene muligheter til innsyn de tidligere ikke hadde. Kaller man forholdet man ønsker å drøfte mistanke om hvitvasking så åpnes dører. Levi (1991) mener begrepets uklarhet er nyttig fordi det er med på å skape politisk konsensus på tvers av partilinjer, venstresiden ønsker bedre innsyn i finansinstitusjoner for å stoppe skatteunndragelser og økonomisk kriminalitet, mens høyresiden er opptatt av terrorisme og organisert kriminalitet ${ }^{2}$.

Reguleringen rettet mot hvitvasking har utviklet seg raskt. Reuter og Truman (2004) gir en oversikt over rettsutviklingen i USA, Europa og globalt frem til 2003. Etter denne tid er den viktigste forandringen at det tredje hvitvaskingsdirektivet ble utviklet i 2005 .

\begin{tabular}{|c|c|c|c|}
\hline Year & United states & Europe & Global \\
\hline 1970 & $\begin{array}{l}\text { Bank Secrecy Act, } \\
\text { Racketeer Influenced and Cor- } \\
\text { rupt Organizations Act (Rico). }\end{array}$ & & \\
\hline 1977 & $\begin{array}{l}\text { Foreign Corrupt Practices Act } \\
\text { (FCPA). }\end{array}$ & & \\
\hline 1980 & & $\begin{array}{l}\text { Measures against the Trans- } \\
\text { fer and Safekeeping of Funds } \\
\text { of Criminal Origin (Council of } \\
\text { Europe). }\end{array}$ & $\begin{array}{l}\text { Offshore Group of Banking } \\
\text { Supervisors (OGBS) estab- } \\
\text { lished. }\end{array}$ \\
\hline 1986 & $\begin{array}{l}\text { Money Laundering Control Act } \\
\text { (MLCA). }\end{array}$ & $\begin{array}{l}\text { Drug Trafficking Offences Act } \\
\text { (UK). }\end{array}$ & $\begin{array}{l}\text { Inter-American Drug Control } \\
\text { Comission of the Organization } \\
\text { of American States (OAS/CI- } \\
\text { CAD) } \\
\text { ICPO - Interpol resolution on } \\
\text { economic and financial crime. }\end{array}$ \\
\hline
\end{tabular}




\begin{tabular}{|c|c|c|c|}
\hline 1988 & \begin{tabular}{|l|} 
Anti-Drug Abuse Act, \\
Money Laundering Prosecu- \\
tion Improvements Act.
\end{tabular} & & $\begin{array}{l}\text { Statement of Principles (Basel } \\
\text { Committee). } \\
\text { UN Convention Against Illicit } \\
\text { Traffic in Narcotic Drugs and } \\
\text { Psychotropic Substances. }\end{array}$ \\
\hline 1989 & & & $\begin{array}{l}\text { Financial Action Task Force } \\
\text { (FATF) established. }\end{array}$ \\
\hline 1990 & Crime Control Act. & $\begin{array}{l}\text { Convention (Strasbourg) on } \\
\text { Laundering, Search, Seizure } \\
\text { and Confiscation of Proceeds } \\
\text { from Crime. }\end{array}$ & $\begin{array}{l}\text { FATF Forty Recommenda- } \\
\text { tions released. } \\
\text { Caribbean FATF established. }\end{array}$ \\
\hline 1991 & & $\begin{array}{l}\text { First Money Laundering Direc- } \\
\text { tive (European Commission). }\end{array}$ & \\
\hline 1992 & $\begin{array}{l}\text { Annunzio-Wylie Money Laun- } \\
\text { dering Act. }\end{array}$ & & $\begin{array}{l}\text { Model Regulations Concern- } \\
\text { ing Laundering Offences Con- } \\
\text { nected to Illicit Drug Traffick- } \\
\text { ing and Other Serious Offenc- } \\
\text { es released (OAS/CICAD) } \\
\text { International Organization of } \\
\text { Securities Commissons (IO- } \\
\text { SCO) resolution on launder- }\end{array}$ \\
\hline 1994 & $\begin{array}{l}\text { Money Laundering Suppres- } \\
\text { sion Act. }\end{array}$ & & $\begin{array}{l}\text { OAS/CICAD declaration of } \\
\text { Principles and Plan of Action } \\
\text { at Summit of the Americas. }\end{array}$ \\
\hline 1995 & $\begin{array}{l}\text { Regulation of funds transfers } \\
\text { Revisions of currency transac- } \\
\text { tion report. }\end{array}$ & $\begin{array}{l}\text { Europol created } \\
\text { Europol Drugs Unit estab- } \\
\text { lished. }\end{array}$ & $\begin{array}{l}\text { Egmont Group of Financial In- } \\
\text { telligence Units of the World } \\
\text { established. }\end{array}$ \\
\hline 1996 & $\begin{array}{l}\text { Simplified suspicious activity } \\
\text { report (SAR), tribal casinos } \\
\text { regulated, exemptions to CTR } \\
\text { reporting. }\end{array}$ & & $\begin{array}{l}\text { FATF Forty Recommendations } \\
\text { revised. International Money } \\
\text { Laundering Information Net- } \\
\text { work (MoLIN) established. }\end{array}$ \\
\hline 1997 & $\begin{array}{l}\text { Proposed rules for money } \\
\text { service business. }\end{array}$ & $\begin{array}{l}\text { Action Plan to Combat Organ- } \\
\text { ized Crime (European Union). } \\
\text { CoE establishes the Select } \\
\text { Committee of Experts on } \\
\text { the Evaluation of Anti-Money } \\
\text { Laundering Measures (PC- } \\
\text { R-EV). }\end{array}$ & $\begin{array}{l}\text { OECD Convention on Com- } \\
\text { bating Bribery of Foreign Offi- } \\
\text { cials in International Business } \\
\text { Transactions adopted. }\end{array}$ \\
\hline 1998 & $\begin{array}{l}\text { Money Laundering and Finan- } \\
\text { cial Crimes Strategy Act. } \\
\text { SARs for casinos and card } \\
\text { clubs. }\end{array}$ & $\begin{array}{l}\text { Joint Action on Corruption in } \\
\text { the private sector (European } \\
\text { Union). }\end{array}$ & $\begin{array}{l}\text { OECD report on Harmful Tax } \\
\text { Practices. } \\
\text { Asia/Pacific Group on Money } \\
\text { Laundering (APG) estab- } \\
\text { lished. } \\
\text { UN Political Declaration and } \\
\text { Action Plan against Money } \\
\text { Laundering. } \\
\text { Model Regulations Concern- } \\
\text { ing Laundering Offences } \\
\text { Connected to Illicit Drug Traf- } \\
\text { ficking and Other Serious Of- } \\
\text { fences (OAS/ CICAD). }\end{array}$ \\
\hline
\end{tabular}




\begin{tabular}{|c|c|c|c|}
\hline 1999 & $\begin{array}{l}\text { Money Services business } \\
\text { regulation issued } \\
\text { First National Money Launder- } \\
\text { ing Strategy } \\
\text { Foreign Narcotics Kingpin } \\
\text { Designation Act }\end{array}$ & & $\begin{array}{l}\text { Model Legislation on Launder- } \\
\text { ing Confiscation and Interna- } \\
\text { tional Co-Operation in Rela- } \\
\text { tion to the Proceeds of Crime } \\
\text { (for civil law jurisdictions) } \\
\text { released by the UN Office for } \\
\text { Drug Control and Crime Pre- } \\
\text { vention (UNDCCP). } \\
\text { OECD Convention on Com- } \\
\text { bating Bribery of Foreign Of- } \\
\text { ficials in International Busi- } \\
\text { ness Transaction entered into } \\
\text { force. } \\
\text { Eastern and Southern Africa } \\
\text { Anti-Money Laundering Group } \\
\text { (ESAAMLG). } \\
\text { UN Convention for the Sup- } \\
\text { pression of the Financing of } \\
\text { Terrorism. }\end{array}$ \\
\hline 2000 & & $\begin{array}{l}\text { Recovering the Proceeds of } \\
\text { Crime Report (United King- } \\
\text { dom) }\end{array}$ & $\begin{array}{l}\text { Wolfsberg Global Anti-Money } \\
\text { Laundering guidelines for Pri- } \\
\text { vate Banking issued. } \\
\text { FATF Report on Non-Cooper- } \\
\text { ative Countries and Territories } \\
\text { (NCCT). } \\
\text { OECD list of } 35 \text { tax havens } \\
\text { with harmful tax practices re- } \\
\text { leased. } \\
\text { Model Legislation on Money } \\
\text { Laundering and Proceeds of } \\
\text { Crime (UNDCCP). } \\
\text { Okinawa G-7 Summit en- } \\
\text { dorses G-7 Finance Ministers' } \\
\text { Report on Actions Against } \\
\text { Abuse of the Global Financial } \\
\text { System. } \\
\text { Financial Stability Forum Re- } \\
\text { port of Working Group on Off- } \\
\text { shore Financial Centers. } \\
\text { Regional Task Force on Anti- } \\
\text { Money Laundering in Latin } \\
\text { America (GAFISUD). } \\
\text { UN (Palermo) Convention } \\
\text { Against Transnational Organ- } \\
\text { ized Crime. }\end{array}$ \\
\hline 2001 & $\begin{array}{l}\text { US PATRIOT Act: Interna- } \\
\text { tional Money-Laundering } \\
\text { Abatement and Anti-Terrorist } \\
\text { Act (Title III). }\end{array}$ & $\begin{array}{l}\text { Second Money Laundering Di- } \\
\text { rective (European Union) }\end{array}$ & $\begin{array}{l}\text { Report on Customer Due Dil- } \\
\text { ligence for Banks (Basel Com- } \\
\text { mitee) } \\
\text { FATF Eight Special Recom- } \\
\text { mendations on Terrorist Fi- } \\
\text { nancing released }\end{array}$ \\
\hline
\end{tabular}




\begin{tabular}{|c|c|c|}
\hline 2002 & $\begin{array}{l}\text { European mandate expand- } \\
\text { ed } \\
\text { Proceeds of Crime Act (UK) }\end{array}$ & $\begin{array}{l}\text { FATF Consultation Paper on } \\
\text { Revisions to Forty Recom- } \\
\text { mendations released. } \\
\text { FATF/IMF/World Bank Agree- } \\
\text { ment on AML Pilot Project for } \\
\text { Assessing Compliance with } \\
\text { Anti-Money Laundering and } \\
\text { Combating the Financing of } \\
\text { Terrorism Standards. } \\
\text { Wolfsberg Statement on the } \\
\text { Suppression of the Financing } \\
\text { of Terrorism. } \\
\text { Wolfsberg Anti-Money Laun- } \\
\text { dering Principles for Corre- } \\
\text { spondent Banking. } \\
\text { International Association of } \\
\text { Insurance Supervisors (IAIS) } \\
\text { Anti-Money Laundering Guid- } \\
\text { ance Notes for Insurance } \\
\text { Supervisors and Insurance } \\
\text { Entities. }\end{array}$ \\
\hline 2003 & $\begin{array}{l}\text { Money Laundering Regula- } \\
\text { tions revised (UK) }\end{array}$ & $\begin{array}{l}\text { New FATF Forty Recommen- } \\
\text { dations released. } \\
\text { UN Convention Against Cor- } \\
\text { ruption. } \\
\text { Wolfsberg Statement on } \\
\text { Monitoring. Screening, and } \\
\text { Searching. }\end{array}$ \\
\hline
\end{tabular}

Kilde: Reuter og Truman 2004 (s. 50-53, 2004).

Ekstra aktivitet ble det etter terrorangrepet den 11. september 2001 hvor reguleringen etter påtrykk fra USA i stor grad ble utvidet i retning av terrorfinansiering.

Når man sammenligner den norske og svenske hvitvaskingsreguleringen kan man konstantere at de er ganske like. Den største forskjellen ligger i at man i Norge fra 2005 har gått et skritt lenger og lovstiftet at banker skal ha et elektronisk overvåkningssystem. Det er kun spare- og forretningsbankene og visse finansieringsselskap som er pliktige å gjennomføre elektronisk overvåkning.

\section{Hvordan kan vi forstå utviklingen?}

Hvordan vi kan forstå og forklare den utviklingen som har skjedd når det gjelder reguleringen av hvitvasking? Innen kriminologien og sosiologien har man ikke viet denne utviklingen nevneverdig oppmerksomhet (Levi 1991). Det har de senere år vært skrevet mye om utviklingen innen samfunnsmessig kontroll og overvåkning, men lite som har tatt opp reguleringen av hvitvasking. 
Det har langt på vei skjedd en stille revolusjon innen kontrollen av næringslivet de seneste 25 årene. 1980 årene ble kjent som de-reguleringens tiår, hvor tanker om konkurranse innen næringslivet og samtidig offentlige og statlige tjenester skulle privatiseres. Det viste seg likevel raskt at det som skjedde i praksis var en bevegelse fra et reguleringsregime til et annet. Det skjedde en restrukturering (Leyshon og Thrift 1997). Ofte gikk man fra statlig rammestyring til omfattende regulering av næringslivet gjennom opprettelsen av en rekke ulike tilsyn, utviklingen av et omfattende lovverk og økt press på næringslivets selvregulering (Larsson 2006). Et annet trekk var en økende formalisering av kontrollen innen finansverdenen. Michael Clarke har treffende beskrevet denne utviklingen:

"... regulation involves the constitution of a form of authority, whether internal or external, to achieve ordering in an area of life that has come to attention as showing tendencies to disorder, perversity or excess. Successful regulation involves the consent of the regulated and hence much effort is devoted to achieving and very often raising standards." (Clarke 2000: 3)

Reguleringen rettet mot hvitvasking må forstås i en bredere samfunnsmessig kontekst. Å hevde at denne reguleringen logisk vokste frem som svar på økte problemer med narkotika eller terror forklarer lite eller ingenting. Reguleringen har også blitt innført $\mathrm{i}$ land med små problemer av denne art og hvorfor skulle man anta at hvitvaskingsregulering var et bedre egnet middel enn andre til å forebygge disse formene for kriminalitet?

For å forstå hva som har skjedd så er det vesentlig å analysere utviklingen som en sammensatt teknisk, samfunnsmessig og ikke minst politisk prosess.

Hvilke drivkrefter kan man se bak utviklingen? Noen av de viktigste er:

- Utviklingen innen finansverdenen

- Den politiske utviklingen

Neoliberalisme

Økt fokus på samfunnsmessig risiko

- Den teknologiske utvikling

- Den generelle utviklingen innen sosial kontroll

Det finnes flere gode grunner for at finansinstitusjoner i dag bør reguleres på en annen måte enn for to eller tre tiår siden. Situasjonen innen finansverdenen har forandret seg radikalt. Forandringene kan oppsummeres i noen punkter.

Det har skjedd en meget betydelig økning i volumet av internasjonale transaksjoner. Vi har i dag et globalt finansmarked som er av et slikt omfang og hvor transaksjonene går så raskt at det nærmest er ufattelig ${ }^{3}$. Den enorme ekspansjonen henger sammen med utviklingen av elektroniske pengesystemer og ekspansjonen 
innen verdipapir og finansmarkedene (Leyshon og Thrift 1997). Det virtuelle finansmarkedet medfører en stor utfordring når det gjelder kontroll opp mot bruk og misbruk av systemet. Dagens finanskrise er et levende eksempel på sårbarheten i dette systemet og hvordan man i praksis er knyttet tett sammen globalt.

Samtidig har banker og finansinstitusjoner og derved også kundene tatt skrittet over til nettet. Nettbank har tatt over en rekke av de gamle oppgavene som bankene tok seg av, som å betale regninger og å overføre penger. Dette medfører en ganske annen kontrollhverdag for finansinstitusjonene, men også for politiet og andre som etterforsker finansielle lovbrudd, skatteflukt med mer.

Det er betegnende at finansinstitusjonene i dag pålegges å arbeide for å bedre "kjenn din kunde" prinsippet, som den elektroniske utviklingen har gitt et ganske annet innehold enn tidligere. Bankdrift har alltid hvilt på et tillitsforhold mellom bank og kunde (Larsson 2002). Tillit var alltid av personlig art og bygget på sosiale relasjoner. Den teknologiske utviklingen har skapt økt avstand til kundene og større grad av upersonlige relasjoner. Når bankene nå pålegges å følge opp kjenn din kunde prinsippet så vil dette med stor sannsynlighet medføre en helt spesiell kjennskap, den automatiserte som kan oppnås gjennom teknologisk overvåkning.

Den teknologiske overvåkningen finnes allerede tilgjengelig. Dataløsningene kan kjøpes og overvåkningssystemer med tilhørende tjenester av ulik art opp mot hvitvasking er allerede et etablert marked. Det finnes egne firma både i Norge og internasjonalt som leverer slike systemer, som drifter dem for kunden og som leverer tjenester, for eksempel såkalte PEP lister som finansinstitusjonene må ha for å kunne utføre sin kontroll av politisk eksponerte personer i følge tredje hvitvaskingsdirektiv.

I så måte er overvåkningen i finansinstitusjonene ikke annet enn en forlengelse av en bredere utvikling i samfunnet. Nils Christie (1993) beskrev hvordan kriminalitetskontroll utviklet seg til en profitabel industri. Denne industrien ser man hvis man eksempelvis besøker Cambridge Symposium on Economic Crime som arrangeres årlig. Compliance er et stikkord, finansinstitusjoner plikter å følge opp et stadig mer omfattende regelverk opp mot hvitvasking, hvis ikke sanksjoneres de ved svartelisting og i verste fall med straffesanksjoner.

Hva gjør man når man ikke vet hvordan man skal følge dette opp? Man kjøper ferdige tjenester og løsninger fra advokater, revisorer og firma som utvikler overvåkningssystemer.

Mye av det man ser i praksis innen feltet hvitvasking beskrives fra andre områder med termen styringsrasjonalitet. Internasjonalt snakker man ikke om overvåkning, men i større grad om governance (Johnston og Shearing 2003). Med governance, som kanskje best kan oversettes med styringsrasjonalitet, sikter man til et fenomen noe bredere enn hva som ofte fanges opp av tradisjonelle kontrollteorier. Det siktes til en måte å styre samfunnet på som har et sett av kjennetegn. Et av disse 
er at myndighetene, ofte politi eller tilsynsmyndigheter, gjennom samarbeid, ved å kjøpe tjenester eller pålegger private aktører å utføre oppgaver, delegerer stadig flere av de forebyggende eller overvåkende oppgavene. Konkret ser en dette ved at politiet samarbeider med private vaktselskaper eller næringslivet på ulike måter (Garland 2001, Gundhus og Larsson 2007). Påleggene som finansnæringen og andre aktører gis om å overvåke sine kunders transaksjoner kan forstås i dette perspektivet. Finansinstitusjonene er i dag gitt politioppgaver, noe de ikke alltid setter like stor pris på.

Bak dette finnes en reguleringslogikk som særlig er opptatt av spørsmålene om sikkerhet og risiko. Sikkerhetsspørsmålet har de senere år nærmest blitt et mantra også innen finansinstitusjonene. Det er utviklet egne sikkerhetsavdelinger $\mathrm{i}$ institusjonene i løpet av de siste årene, en av deres oppgaver er hvitvasking ${ }^{4}$. Man kan undres over hvordan verden før 2001 fungerte?

Denne utviklingen åpner opp for en rekke problemstillinger. En av de mest tydelige er at det påvirker skillet mellom det private og offentlige. Eller er det uproblematisk at finansinstitusjoner blir statens overvåkere? Bankvirksomhet pleide å være noe av det mest private man kunne forestille seg, i dag er det ikke slik lenger, hva du gjør i banken er et offentlig anliggende.

Et annet moment er at denne overvåkningen ofte fungerer ekskluderende, personer og hele grupper svartelistes. Grupper som av ulike grunner er marginalisert fra før utsettes for enda mer overvåkning og mistenkeliggjøring (Young 2002). Systemet fungerer ikke inkluderende, men utstøtende, og vil kunne forsterke segregeringstendenser som allerede finns i samfunnet rettet mot definerte risikogrupper. I dag er alle avhengig av bankkonto, samtidig er det en realitet at enkelte ikke får mulighet til å opprette konto, eller at deres muligheter for å benytte denne innskrenkes sterkt.

Et annet moment som er interessant er at det tidvis kan synes som myndighetene har glemt bakgrunnen for innføringen av hvitvaskingsreguleringen. Det virker som det har skjedd en målforskyving i retning av regleverket selv. Diskusjonene om reguleringen i dag dreier seg i stadig mindre grad om systemet fanger opp midler som stammer fra narkotika, terror eller organisert kriminalitet. I stedet er man stadig mer opptatt av regelverket og reguleringen i seg selv. Regelverket blir et mål i seg selv. Det er interessant å se at NOU 2007:10 som behandler det tredje hvitvaskingsdirektivet knapt vier spørsmålet om bakgrunnen for dette noe særlig oppmerksomhet. Prinsipielle spørsmål, som omfanget av hvitvasking eller effektene av reguleringen nevnes knapt, i stedet vier man mye plass til dypsindig ordkøyving om reglenes ordlyd og intensjoner. Det kan være flere grunner til hvorfor det er slik. En er at denne NOUen primært er skrevet av jurister. En annen er nok at dette regleverket er noe man er pliktig til å innføre i norsk rett, hvorfor demonstrere eller stille slike spørsmål da? 
En siste grunn henger nok sammen med at denne reguleringen har fått preg av å ha blitt hva Niklas Luhmann kalte et autopoietisk system (Luhmann 1995). Reguleringen har blitt et lukket univers, et selvopprettholdende og selvrefererende system som følger sine egne lover. Kritikk utenfra vil raskt fremstå som irrelevant, noe som ikke følger spillereglene.

\section{Metodiske betraktninger}

Verken i Norge eller Sverige finnes det foreliggende statistikk over hvitvaskingsreguleringens kostnader. Det eksisterer heller ikke noen forskning fra disse landene som går inn på dette spørsmål. Mer overraskende er det kanskje at det ikke finnes noen klar oppfatning over kostnadene innen bank og finansbransjen selv. Vi var derfor henvist til å kontakte bankene og deres bransjeorganisasjoner for å få deres oppfatning av kostnadene.

Den svenske delen av undersøkelsen fikk etter hvert betydelige problemer med å få i stand intervjuer. Særlig etter Forexsaken i Sverige høsten 2008, hvor selskapet Forex ble ilagt en bot på 50 millioner for mangelfull oppfølging av hvitvaskingsreguleringen, fikk noen respondenter kalde føtter og avlyste inngåtte intervjuer.

I utgangspunktet skulle vi samle inn kunnskapen om kostnadene via en spørreskjemaundersøkelse. Vi var klar over at undersøkelses- og meldeplikten gjaldt et stort antall bedrifter og at vi av resurshensyn var nødt til å gjøre et utvalg av disse. Vi fant raskt ut gjennom intervjuer med ansatte innen banknæringen at det ikke ville gi noe godt resultat å sende ut en enquette til finansinstitusjonene når svært få hadde kunnskap om de reelle kostnadene. Mangelen på strukturert kjennskap til kostnadene ved gjennomføringen av hvitvaskingsreguleringen hos de aktuelle bedrifter har gjort at vi ble tvunget til å konsentrere ressursene på dybdeintervjuer med formål å kartlegge respondentenes kunnskap på feltet. Undersøkelsen ble derfor langt på vei en eksplorativ undersøkelse. Vår tanke om at finansbedriftene skulle være interesserte og velvillig innstilt til å besvare våre spørsmål viste seg ofte å være noe optimistiske.

Undersøkelsen ble utført på noe ulikt vis i Sverige og Norge. Det kom av at de svenske kildene $\mathrm{i}$ utgangspunktet var villige til å sette av ressurser til å gå igjennom og besvare et strukturert skjema med spørsmål vedrørende kostnadene (se nedenfor). Ut fra dette fikk man relativt strukturerte overslag over kostnadene. Dette skjema ble også sendt til utvalgte norske kilder uten at det ble besvart ${ }^{5}$.

Både i Sverige og Norge utførte vi ustrukturerte intervjuer av bankpersonell, ansatte innen myndighetene som utfører tilsyn og regulering, i bankforeningene og andre med kompetanse på feltet. 


\section{Kostnader knyttet til hvitvaskingsreguleringen i bankene}

Selv innen internasjonal forskning finnes det svært få som har forsøkt å kalkulere hvitvaskingsreguleringens kostnader. Reuter og Truman (2004) har presentert noen estimater, men selv i deres undersøkelse er det ikke klart hvordan de har kommet frem til disse. De bygger på "biter av amerikansk og brittisk informasjon" (s. 93). Estimatene er som de selv sier, svært omtrentlige. Anslaget for kostnadene i USA i 2003 er på 7 milliarder dollar, noe som utgjør 25 dollar per innbygger. Av dette er 4 milliarder utgifter innen private bedrifter, mens de offentlige utgiftene anslagsvis er på 3 milliarder. Omgjort til Norske forhold skulle det da bety at man hadde en utgift på ca. 600 millioner kroner årlig. Derav omtrent 200 mill til det offentlige.

\section{Norske estimater}

Man kan relativt enkelt skaffe tall for hva dataløsninger og oppfølgingen av den rent tekniske overvåkningen koster. Personalkostandene er derimot langt vanskeligere å estimere. Følgende kostnader er mulig å skille ut:

- Utgifter til de som har hvitvasking som sin hovedoppgave. Det er kanskje bortimot 20 ansatte i bankene Norge som arbeider med oppgaver opp mot flaggede saker og mistenkelige transaksjoner. Vanligvis har de også flere andre oppgaver, mange av dem arbeider ved bankenes sikkerhetsavdelinger.

- Utgifter til hvitvaskingsansvarlig og andre som hare lederoppgaver.

- Utgifter til arbeid med hvitvaskingsproblematikken i bankforeningene. Det kan være betenkninger, innspill, faglig oppdatering med mer.

- Utgifter fordelt til alle med personalkontakter som skal ha overvåkning som en oppgave. Det er vanskelig å tallfeste hvor stor del av arbeidsdagen dette utgjør. Dette vil nok variere etter bl.a. bankens størrelse, type bank og beliggenhet. Det er vanskelig å skille det fra andre oppgaver relatert til det å opprettholde kundeforhold. Dette er en post som kommer til å vokse enormt de nærmeste årene med innføringen av det tredje direktivet.

- Utgifter til faglig oppdatering av alle i Norsk banknæring. Med over 12000 ansatt i Norsk bank og finansnæring som skoleres annen hvert år i en hel dag, så blir det 6000 dagsverk årlig bare i opplæring.

På toppen av dette er det utgifter til eksterne bedrifter som leverer tjenester, det er blant annet dataløsninger og juridisk bistand. I Norge er det hovedsakelig bedriften EDB businesspartner som bidrar med dataløsninger.

Det finnes noen løselige beregninger av utgiftene, men disse har opplagte mangler. Eiterå i Sparebank 1 beregnet i 2005 norsk banknærings utgifter i forbindelse med hvitvaskingsreguleringen å være på 100 millioner årlig. Estimatet refereres ofte i næringen og få har direkte motsagt dem. 
Utgiftene fordelte seg på følgende poster:

- Investering i elektroniske overvåkningssystem - ca. 50 millioner årlig.

- Driftsutgifter på systemet per år $\quad$ ca. 10 millioner årlig

Drift / vedlikehold

Oppdatering av regler og regelverk

- Ressursbruk på antihvitvasksarbeidet per år ca 40 millioner

Opplæring av medarbeidere

Saksbehandling

Oppfølging av løpende saker

Ved EDB Businesspartner, som er den absolutt største som leverer hvitvaskingsprogram og service i norsk finansnæring, anslår man at kostnadene årlig for deres kunder ligger på cirka 50 millioner årlig for den elektroniske overvåkningen. Denne bedriften har de fleste sparebanker, men mangler store kunder som DnBNor og Nordea. Det er ikke urealistisk å anta at disse bruker en like stor sum på denne overvåkningen. Det vil si at den elektroniske overvåkningen koster rundt regnet 100 millioner årlig for norsk bankvesen.

Det flagges årlig ti tusener av transaksjoner ved den elektroniske overvåkningen. Disse må gjennomgås manuelt. Dette arbeidet anslås i gjennomsnitt å ta mindre enn 5 minutter per sak. Av 28500 flagginger som EDB hadde gått gjennom ble 1600 rapportert til Økokrim.

Det er som nevnt vanskelig å skille ut alle personalkostandene ved denne aktiviteten, men det er ikke urealistisk å anta at disse utgiftene er like store som de som går til den elektroniske overvåkningen. Et estimat på minimum 200 millioner årlig for norsk banknæring er derfor ikke usannsynlig. Sammenlignet med de svenske og amerikanske tallene virker dette tallet realistisk.

\section{Svenske estimater}

Den svenske studien baseres på bankstatistikk fra 2006. Under 2006 eksisterte det 51 forretningsbanker og 68 sparebanker i Sverige. Bankene ble inndelt etter størrelse. Siden intervjuedes en eller flere banker i hver størrelsesgruppe om sine detaljerte kostnader for å gjennomføre hvitvaskingsreguleringen og loven om finansiering av terrorisme i løpet av år 2007. Dessuten har de intervjuede bankene anslått kostnadene med å gjennomføre det tredje hvitvaskingsdirektivet.

Bankene ble bedt om å beregne kostnadene for følgende tiltak:

- Bedriftens styre eller administrerende direktør skal fastesett interne regler med sikte å forhindre hvitvasking eller finansiering av spesielt alvorlig kriminalitet. 
- Det skal finnes en sentral funksjonsansvarlig.

- Ansatte skal gjennomføre identitetskontroller. Det bør understrekes at identitetskontroller må utføres også av andra grunner enn for å forhindre hvitvasking.

- Transaksjoner skal granskes.

- Dokumenter skal arkiveres.

- Ansatte skal utdannes og fortløpende holdes oppdatert på feltet.

- Mistenkelige transaksjoner skal anmeldes til Finanspolisen ${ }^{6}$.

- Hvitvaskingsregister skal opprettes og driftes.

- Installasjoner og drift av teknisk utrustning.

- Gransking av informasjon om betaleren som skal følge overføringer av midler i henhold til EG - forordning 1781/2006.

- Kostnader knyttet opp til å gjennomføre tredje hvitvaskingsdirektivet.

Siden har det blitt beregnet hvor stor prosentvis andel hvitvaskingstiltakene utgjør av respektive banks årlige omsetning. Deretter har de prosentvise andelene av de intervjuede bankene blitt brukt for å beregne de andre bankenes hvitvaskingskostnader innen respektive størrelsesgruppe basert på deres omsetningstall. En utregning av samtlige banker har siden gitt den estimerte kostnaden for bankenes tiltak for å bekjempe hvitvasking.

\begin{tabular}{|c|c|c|c|}
\hline $\begin{array}{l}\text { Antall } \\
\text { forretningsbanker }\end{array}$ & $\begin{array}{l}\text { Omsetningstall } \\
\text { i millioner kr }\end{array}$ & $\begin{array}{l}\text { Kostnader for } \\
\text { hvitvaskkontroll kr }\end{array}$ & $\begin{array}{l}\text { Prosentuell andel av } \\
\text { omsetningen }\end{array}$ \\
\hline 5 & $\begin{array}{c}1268192 \\
-528370\end{array}$ & 273148000 & $0.006 \%$ \\
\hline 2 & $61471-56164$ & 27086530 & $0.023 \%$ \\
\hline 7 & $34285-13851$ & 10644830 & $0.007 \%$ \\
\hline 12 & $9889-5249$ & 47478400 & $0.051 \%$ \\
\hline 25 & $4540-5$ & 3138520 & $0.007 \%$ \\
\hline
\end{tabular}

Sum kostnader for forretningsbankenes hvitvaskingskontroll: $\quad 361496280 \mathrm{kr}$.

\begin{tabular}{|c|c|c|c|}
\hline Antal sparbanker & $\begin{array}{l}\text { Balansomslutning } \\
\text { miljoner kr }\end{array}$ & $\begin{array}{l}\text { Kostnader for } \\
\text { hvitvaskkontroll kr }\end{array}$ & $\begin{array}{l}\text { Prosentuell andel } \\
\text { av omsetningen }\end{array}$ \\
\hline 10 & $14515-3455$ & 29960970 & $0.051 \%$ \\
\hline 58 & $<3455$ & 4087300 & $0.007 \%$ \\
\hline
\end{tabular}

Sum kostnader for sparebankenes hvitvaskingskontrol: Totalt: 
Et forhold som spesielt bør fremheves er mangelen på detaljerte kalkyler og regnskap som dekker de særskilte tiltakene som er iverksatt mot hvitvasking. Selv om det forekommer at de har oversikt over kostnadene for visse prosjektbaserte opplegg så mangler det likevel en detaljert oversikt over kostnadene i sin helhet. Dette kan naturligvis henge sammen med at man ikke opplever de faktiske kostnadene som spesielt tyngende og derfor fører dem under andre poster. Vi har ikke påtruffet en eneste bedrift hvor man har hatt et detaljert system som har dokumentert utgiftene forbundet med hvitvaskingsreguleringen.

Et tiltak vi tror skulle kunne medføre betydelig bedre oppfølging av reglene mot hvitvasking skulle være om Kredittilsynet i Norge og Finansinspeksjonen i Sverige regelmessig krevde at de bedrifter som myndighetene har tilsyn over skulle gi en detaljert dokumentasjon av sine kostnader opp mot hvitvasking. Dette skulle tvinge bedriftene til å strukturere virksomheten mot hvitvasking og ville medføre at forskning og evaluering av utfallet av reguleringen ble langt lettere å utføre.

\section{Er reguleringen en suksess?}

Det har blitt reist kritiske røster mot hvitvaskingsreguleringen, primært ut fra de relativt magre resultatene $i$ form av straffesaker mot narkotika og andre former for alvorlig kriminalitet dette har resultert i. Michael Levi påpekte allerede i 1991 at hovedhensikten med reguleringen ikke var kampen mot narkotika, men at dette var et vikarierende motiv. Narkotika var godt egnet som fiende man kunne samle støtte for reguleringen med. Hovedmålsetningen var i stedet å bryte ned bankenes diskresjon og vern av sine kunder slik at myndighetene lettere kunne få tilgang til informasjon i bankene. Derav undertittelen The death of bank secrecy in the $U K$. Tidligere hadde de tidvis store problemer med å få informasjon fra bankene i forbindelse med skatteunndragelser og andre former for finansielle lovbrudd. Hvis målet var å åpne bankene for kontrollmyndighetenes innsyn så kan en si at reguleringen har vært en suksess.

Det kan hevdes at dagens reguleringssystem er en grei pris å betale i kampen mot alvorlige onder som organisert kriminalitet og terror. Reguleringen viser at myndighetene gjør noe med problemene og at de tetter igjen noen av de mest åpenbare mulighetene til å håndtere midler som stammer fra kriminalitet innen det åpne finanssystemet. Den lukkede finansverdenen ble nok dessuten opplevd som en anomali i dagens gjennomregulerte samfunn.

Mange vil nok hevde at innskrenking av sider ved det sivile samfunn, personvernet og den personlige handlefrihet samt en viss følelse av ubehag er prisen vi må betale for større grad av sikkerhet. Kanskje, det er vanskelig og noe ufint å problematisere innsatsen mot så grusomme onder som terror og organisert kri- 
minalitet hevdes å være. Det er spesielt vanskelig når en har liten oversikt over de totale kostnadene ved denne reguleringen og hva den faktisk munner ut i. En kost / nytte analyse av reguleringen finnes knapt. Et annet spørsmål er hvordan man skal vekte tapet av personvern, økt utstøtning og følelsen av ubehag for noen opp mot en eventuell gevinst i form av etterretningsinformasjon og dommer.

Det er også interessant å se at begrunnelsen for reguleringen flyttes etter hvert som tiden går. Det pleide å være å forebygge narkotikakriminalitet og andre former for alvorlig kriminalitet, så kom terror inn, siden har fokuset forflyttet seg over til overvåkningens verdi som etterretningskilde. Et mål som i liten grad er åpent for innsyn, kontroll og som vanskelig lar seg måle på enkelt vis.

En kan spørre hvor reguleringen vil ende. Lite tyder på at innsatsen mot hvitvasking vil slutte med det tredje direktivet. Utviklingen har sin egen dynamikk. Det er enkelt å argumentere for mer, hvis det synes å fungere så kan man lett spørre etter mer, samtidig er manglende suksess et godt argument for mer av det samme. Dessuten har mange gjort seg en karriere innen feltet som eksperter eller ved å utvikle varer og tjenester til bruk i innsatsen mot hvitvasking.

\section{Effekter av reguleringen}

"... there is an absence of systematic evidence that it (the AML regime) has made money laundering more than marginally more difficult for those who need to clean dirty money or finance terrorism." (Reuter og Truman 2004, s. xi)

Det er vanskelig å skille ut de rene hvitvaskingssakene og hva slags forhold disse består av i den offisielle statistikken som i Norge utgis av Økokrim (EFE 2007, Larsson 2008). Det samme understrekes innen internasjonal litteratur (Reuter og Truman 2004). Det påpekes at reguleringens effekter når det gjelder å avsløre eller oppdage hvitvasking eller primærforbrytelsene er begrenset, men at overvåkningen fanger opp andre former for kriminalitet, at den har verdi som etterretningsinformasjon og i forbindelse med etterforskning rettet mot kjente kriminelle miljøer eller allerede begåtte forbrytelser.

Om en betegner dette som en suksess eller ei avhenger selvsagt av hva målet for reguleringen er, hva man sammenligner med, og om man i utgangspunktet har realistiske mål.

Målet for reguleringen har sammen med avgrensingen av begrepet hvitvasking endret seg i løpet av de siste par tiår. Følgende trekkes ofte frem:

- $\quad$ A bekjempe eller forebygge primærforbrytelsene ${ }^{8}$. I utgangspunktet var det narkotikalovbrudd, dette er senere utvidet betydelig til organisert kriminalitet og etter hvert er det all kriminell aktivitet som generer penger. 
Indikatorer på suksess burde da være om disse har gått ned og om dette kan knyttes opp mot reguleringen. Å dokumentere dette på en god måte viser seg å være nærmest umulig. En kan også analysere effektene ut fra et mer rent strafferettslig perspektiv. Spørsmålet blir da om man oppdager lovbrudd gjennom overvåkningen, utfallet av etterforskningen, siktelser, oppklaringsprosenter og antall dommer.

- Medvirkning til hvitvasking. Ved å tette igjen mulighetene for hvitvasking av midler antas det at man indirekte kan påvirke kriminaliteten. Et mål på effektivitet kan derved bli om man makter å tette hullene. Reguleringen blir et mål i seg selv. Godt og effektivt regelverk antas å ha en positiv verdi i seg selv, hvis det følges opp. Ved å straffe vaskere eller bedrifter som ikke følger opp reguleringen kan man nå målet om effektiv hvitvaskingsbekjempelse. Et slikt perspektiv kan muligens kalles reguleringsdogmatisk, man antar at regler og regulering medfører at det forebygger uten at dette underbygges med annet enn sporadiske data.

- Beskyttelse av de finansielle institusjoner. Det fremheves i dag at en viktig side ved reguleringen er beskyttelse av institusjonene selv mot misbruk og lovbrudd. Dette faller i så måte inn under sikkerhetsoppgavene i finansinstitusjonene. Reuter og Truman (2004) påpeker at dette målet et godt stykke på vei synes oppnådd: "Nevertheless, the global regime appears to have largely achieved one of its primary goals, which is to eliminate the threat from money laundering to the integrity of banking systems, at least for large institutions in the major jurisdictions." (s. 136)

- Overvåkning og etterretning. I løpet av de senere år har den etterretningsmessige verdien av MT (mistenkelige transaksjoner) meldingene blitt fremhevet ${ }^{9}$. Det er de senere årene opprettet egne finansielle etterretningsenheter i Norge i Økokrim (EFE), mens den i Sverige er lagt i Finanspolisen. Meldingene har som leder i EFE opplyste en egenverdi som kilde til informasjon om en del av verden som vanligvis er lukket for innsyn for politi og myndigheter.

- Som kilde ved etterforskning. MT rapporter benyttes i forbindelse med etterforskning av en rekke ulike sakstyper og ellers i det proaktive arbeidet opp mot identifiserte kriminelle grupper.

- Kampen mot terrorfinansiering. Etter 11. september 2001 har regelverket mot hvitvasking blitt skjerpet betraktelig, bl.a. gjennom det tredje hvitvaskingsdirektivet. Mye av fokuset i dag er rettet mot midler som på et eller annet vis kan knyttes opp mot terrorisme og andre globale problemer, som korrupsjon og plyndring av stater (Reuter og Truman 2004). 
Ut over dette er det selvsagt høyst sannsynlig at reguleringen også har flere underliggende målsetninger som sjelden fremheves, men som likevel kan være minst like viktige som de som vanligvis nevnes. Bankenes og finansinstitusjonenes sekrettese var i lang tid et hinder for finansiell etterforskning, særlig i skattesaker, men også i annen finansiell kriminalitet. Det synes klart, som Levi (1991) påpeker, at hvitvaskingsreguleringen har vært en effektiv brekkstang for myndighetene for å få tilgang til informasjon fra disse bransjer. I en verden hvor den globale økonomien vokste med stor hastighet er ønsket om innsyn og en viss overvåkning av pengenes bevegelser høyst forståelig. Hvitvaskingsreguleringen henger i så måte sammen med utviklingen innen kontroll av innsidehandel, opprettelsen av verdipapirsentralen og valutaregisteret for å nevne noen.

Om man skal kunne uttale seg hvorvidt reguleringen faktisk når sine mål må man derfor gjøre det klart hvilke mål man faktisk sikter til. Flere av de uttalte målsetningene nevnt ovenfor er det høyst problematiske å måle effekten av. Den hittil mest anerkjente gjennomgangen av dette er Reuter og Trumans bok "Chasing dirty money". De påviser at effektene av reguleringen er vanskelig å dokumentere og høyst usikre når det gjelder primærkriminaliteten, vaskingen og bekjempelsen av terror.

Om hvitvaskingsreguleringen skal oppfattes som suksess eller fiasko avhenger selvsagt også av hva man sammenligner med. En kan muligens hevde at det begrensede antall straffesaker i forhold til antallet MT rapporter virker nedslående. Men sammenligner en med annen kriminalitet, særlig økonomisk kriminalitet kan en hevde at bildet ikke er enestående. Hvor mange saker med kursmanipulasjon eller innsidehandel føres årlig for retten? Frem til 2001 hadde man i Norge kun én fellende dom innen innsidehandel (Larsson 2001). Politiet sliter med lav oppklaringsprosent overfor en lange reke former for lovbrudd som skulle være langt enklere å oppklare og iretteføre enn hvitvasking. Det er stort sett de enklere formene for økonomisk kriminalitet som fyller kriminalstatistikken, bedragerier, regnskapslovbrudd og skattelovbrudd av enkel art.

Et annet moment som gjør det svært vanskelig å besvare spørsmålet om hvilke effekter reguleringen har hatt er den manglende forskningsmessige kunnskapen på feltet. Vi vet langt på vei ikke utfallet av reguleringen, vi har ikke noen god viten om effektene på primærforbrytelsene eller terror, for å nevne de mest sentrale. Vi kjenner heller ikke til hvor mye penger som vaskes og om reguleringen har hatt noen dokumenterbar forebyggende effekt. Svært mye av det som hevdes om hvitvasking bygger på tynne data, enkeltsaker og tro, ikke på systematisk innsamlet viten.

Den globalt utbredde reguleringen har ikke oppstått som svar på analyser eller forskningsbasert kunnskap, men er i stedet sprunget ut av praktikeres, etterforskere og andres, behov og den commensensiske sannheten at det er smart å gå etter pengene. 
Det viktigste for praktikerne er å gjøre jobben. Det vil si overvåke, etterforske og prosedere i sakene. Ofte oppfattes de underliggende målsetningene bak reguleringen som av mindre betydning. Siden har lovgivere og andre fulgt opp praktikernes ønsker med et etter hvert stort og komplekst regelverk. Spørsmålet er selvsagt om denne veien er fruktbar.

Når det gjelder mulighetene for å oppdage og bekjempe hvitvasking så er mulighetene svært forskjellige etter om det er snakk om tradisjonell kriminalitet eller økonomiske lovbrudd. Den økonomiske kriminaliteten begås vanligvis innen legal næringsvirksomhet. Det finnes derfor vanligvis ingen anledning til å mistenke de finansielle transaksjonene som bedriftene utfører. Det er først i ettertid når selvangivelsen er levert det er mulig å bringe på det rene et skattelovbrudd eller de økonomiske lovbrudd oppdages i sammenheng med en konkurs eller likvidasjon. Dette resonnement gjelder også for privatpersoners skatteunndragelser. Konklusjonen av dette blir at hvitvaskingsbestemmelsene kun kan antas ha en begrenset effekt på vaskingen av utbyttet fra økonomisk kriminalitet. Derimot kan hvitvaskingsreguleringen gi viktige bidrag i forbindelse med etterforskning av saker og til etterretningsformål. Informasjonen samlet ved MT rapporter er viktig som etterretningskilde og kan gi viktig innblikk i lukkede miljøer.

Man kan anta at hvitvaskingskontrollen i liten grad avslører hvitvasking, men i den grad man allerede har mistenkte eller miljøer politiet følger så kan informasjonen benyttes med utbytte.

Har hvitvaskingsreguleringen preventive effekter? Følgende effekter er plausible:

- Begrenser muligheter. Man kan anta at reguleringen faktisk har en viss preventiv effekt, $i$ alle fall mot at banker benyttes åpenlyst til hvitvasking eller annen finansiell kriminalitet. Det blir, særlig med det tredje direktivet på plass, noe tyngre og risikabelt å håndtere midler som stammer fra kriminalitet (kanskje med unntak av økonomisk kriminalitet).

- Omfordelingseffekter. Det er å anta at reguleringen medfører tilpassninger. Lovbrytere velger andre måter å plassere pengene, mest kjent er kanskje flyttingen av penger ut av landet. Midlene kan brukes til kjøp av hoteller, puber, beach houses, bygging av egne hus og annet i Pakistan, Brasil, Thailand eller andre land.

- Økt sikkerhet i bankene mot misbruk. Reguleringen innfører tiltak som vil bedre sikkerheten mot misbruk i og av bankene.

- Betydningen av å ha regleverket på plass for banker som driver internasjonal virksomhet. I mange vestlige land, kanskje særlig i USA, vurderes bankene opp mot hvor gode de er til å følge opp regelverket og reguleringen. Man bedømmes etter grad av compliance. 
Til slutt kan man stille spørsmålet om kostnadene ved hvitvaskingsreguleringen kan forsvares ut fra de oven nevnte effekter. Det kan selvsagt hevdes at så lenge ingen kan påvise alternative metoder for å oppnå samme mål så er det på sin plass å bygge videre på det pyramidale hvitvaskingsbyggverket.

Et grunnleggende problem med at man internasjonalt har valgt dette sporet i kampen mot ulike sosiale onder er at andre måter å arbeide forebyggende ikke prioriteres like mye. Det finnes andre tilnærminger som kunne vært mer kostnadseffektive og som kanskje vil medføre mindre samfunnsmessige skadevirkninger enn hvitvaskingsreguleringen.

\section{Kostnader i bankene}

Våre anslag er at hvitvaskingsreguleringen koster norsk bannæring anslagsvis 200 millioner årlig. Dette vil øke betydelig med innføringen av det tredje hvitvaskingsdirektivet som pålegger bankene en rekke nye oppgaver. Nye dataløsninger alene vil koste næringen rundt 200 millioner kroner ${ }^{10}$. I Sverige ligger de årlige utgiftene på rundt 400 millioner SEK årlig. Dette til tross for at man der ennå ikke har innført elektronisk overvåkning i bankene.

Hvis man legger til kostnadene i det offentlige, som hos Reuter og Hagan (2004) anslagsvis lå på 3/7 deler så er det ikke usannsynlig at man for Norges vedkommende kommer opp i minimum 300 millioner. På toppen av dette kommer selvsagt utgifter andre bedrifter med meldeplikt måtte ha.

Spørsmålet er om disse summene er små eller store, akseptable eller ei. Sammenlignet med kostnadene innen justissektoren for øvrig så er 300 - 400 millioner kroner småpenger. Politiet alene koster det norske samfunn rundt 10 milliarder årlig. Spørsmålet er selvsagt hva som kommer ut av denne innsatsen og om man kunne gjort dette annerledes.

\section{Forslag til tiltak}

Studien konkluderer med at kunnskapen om kostnadene av hvitvaskingsreguleringen både innen det offentlige og det private er mangelfull. De overslag som dokumenteres $i$ vår studie er ytterst røffe og omtrentlige. Det vil være av stor interesse å ha en bedre oversikt over hvilke konkrete opplegg og tiltak som utføres i finansnæringen og kostnadene forbundet med det. Det vil være viktig for bedriftene selv, som dokumentasjon av hva de gjør. For tilsynsmyndighetene, i Norge Kredittilsynet og i Sverige Finaninspeksjonen, for at de bedre skal kunne ha oversikt over oppfølgingen av regelverket og omfanget av det som skjer innen bedriftene. Det er viktig politisk og samfunnsmessig å kjenne til omfanget og konsekvensene av reguleringen på feltet for å kunne forholde seg til kostnadene og den nytten vi kan ha av det. 
Vi foreslår at respektive lands tilsynsmyndigheter årlig følger opp tilsynet med en obligatorisk kartlegging av kostnadene forbundet med reguleringen i de enkelte bedrifter. Det skulle være en enkel sak å utvikle et standardisert skjema, bygget på vår analyse, med spesifiserte utgiftsposter som bedriftene selv fyller ut og sender inn.

Et annet tiltak for å kunne vurdere effektene av innsatsen er bedret hvitvaskingsstatistikk fra EFE ved Økokrim og Finanspolisens side. Dagens statistikk er en driftsstatistikk som har relativt liten verdi for forskere eller analytikere som ønsker å gå inn på effektene av reguleringen. Det enorme materialet som Økokrim / Finanspolisen besitter skulle uten større problemer kunne gjøres lettere tilgjengelig til bruk i forsknings og analyseøyemed. En bedret statistikk burde la seg utvikle ved å rådføre seg med analytikere i egen etat og forskere som arbeider med problemstillingen.

Det er i det hele et stort behov for mer forskning og analyser på utfallet av hvitvaskingsreguleringen. I dagens situasjon er kunnskapshullene så store at det er vanskelig å uttale seg med noen større grad av presisjon om hva effektene av reguleringen er. Dette er ikke bare betenkelig ut fra et forskningsmessig, men også fra et polisiært ståsted. Skal det kunne oppnås bedre resultater er det vesentlig at man kan dokumentere hva som synes å fungere og hva som ikke gjør det. Det er også viktig å gi bankene og andre som legger ned betydelig arbeid på å regulere i egne næringer tilbakemeldinger om hva deres rapporter ender opp i. Det uttrykkes tidvis klare frustrasjoner over at det gis lite feedback fra politi og rettsvesen som kan virke motiverende. I så måte vil en bedret statistikk kunne gi finansnæringen og andre aktører noe tilbake.

\section{Referanser}

Bye, Ronald og Finn Sjue, 2008: Overvåket, Gyldendal, Oslo.

Christie, Nils, 1993: Kriminalitetskontroll som industri, Universitetsforlaget, Oslo. Duyne, Petrus c. van, 2003: "Foreword: Greasing the organisation of crime in Europe", i Duyne, Lampe og Newell (eds.): Criminal Finances and Organising Crime in Europe, Wolf Legal Publishing, Nijmegen.

Duyne, Petrus C. van og Michael Levi, 2005: Drugs and Money. Managing the drug trade and crime-money in Europe. London, Routledge.

EFE - Enheten for finansiell etterforskning, 2007: Arsrapport 2006. Økokrim, Oslo.

Finansdepartementet, 2002: Utkast til lov om forebyggende tiltak mot hvitvasking av utbytte og finansiering av terrorisme (Hvitvaskingsloven), Rapport fra arbeidsgruppe oppnevnt av Finansdepartementet 12. Juni 2002, Oslo. Garland, David, 2001: The Culture of Control, Oxford University Press. 
Gundhus, Helene og Paul Larsson, 2007: "Policing i et norsk perspektiv", i Gundhus, Larsson og Myhrer (red): Polisicer virksomhet. Hva er det - hvem gjør det?, PHS forskning nr. 7, Politihøgskolen, Oslo.

Johnston, Leo and Clifford Shearing, 2003: Governing Security. Explorations in Poloicing and Justice, Routledge, London.

Larsson, Paul, 2001: Hvitere enn hvitsnippkriminalitet. En studie av reguleringen av kriminalitet $i$ verdipapirmarkedet, Rapport Norges forskningsråd, Oslo.

Larsson, Paul, 2002: I lovens grenseland. Pax forlag, Oslo.

Larsson, Paul, 2006: "Developments in the regulation of white-collar crime in Norway", i Journal of Financial Crime.

Larsson, Paul, 2008: "§ skyte spurv med kanon? Noen konsekvenser av hvitvaskingsreguleringen i finansnæringen", i Tage Alaletho og Daniel Larsson (red.) Den ljusskygga ekonomin. Organiserad och ekonomisk brottslighet, University of Umeå, Sverige.

Larsson, Paul, 2008b: Organisert kriminalitet, Pax forlag, Oslo.

Levi, Michael, 1991: "Regulating money laundering. The Death of Bank Secrecy in the UK", British Journal of Criminology, vol 31.

Levi, Michael, 2003: "Following the criminal and terrorist money trails", i Duyne, Lampe og Newell (eds.): Criminal Finances and Organising Crime in Europe, Wolf Legal Publishing, Nijmegen.

Leyshon, Andrew and Nigel Thrift, 1997: Moneyspace. Geographies of Monetary Transformation. Routledge, London.

Luhmann, Niklas, 1995: Autopoiesis II. Udvalgte tekster af Niklas Luhmann. Politisk Revy, København.

Naylor, R.T. 2002: Wages of crime. Black Markets, Illegal Finance, and the Underworld Economy, Cornell University Press, Ithaca and London.

NOU 2007: 10. Om tiltak mot hvitvasking og terrorvirksomhet. Gjennomføringen av EØS-regler tilsvarende EUs redje hvitvaskingsdirektiv $i$ norsk rett.

Reuter, Peter and Edwin M. Truman, 2004: Chasing Dirty Money. The Fight Against Money Laundering, Institute for International Economics, Washington.

Rider, Barry, 2004: "More of the same!", Journal of Money Laundering Control, vol. 7 , nr. 4.

United Nations Office for Drug Control and Crime Prevention, 1998: Financial Havens, Banking Secrecy and Money Money-Laundering, Report, New York.

Unger, Birgitte, 2006: White money. The Amounts and the Effects of Money Laundering in Industrialized Countries, Edward Elgar, Cheltenham, UK (bokmanus).

Young, Jock, 2002: “Crime and social exclusion", i Maguire, Morgan and Reiner (eds): The Oxford Handbook of Criminology, Third ed. Oxford. 


\section{Noter:}

Financial Action Task Force.

Terrorisme avgrenses også på høyst ulike måter, man har eksempelvis tre ulike terrorlister, en utviklet av USA som er meget omfattende, en EU liste og en relativt kort fra FN (Bye og Sjue 2008). Begrepet er i seg selv problematisk, noe også organisert kriminalitet er. Det finnes mange ulike definisjoner og avgrensinger av organisert kriminalitet (Larsson 2008b). Disse uklarhetene blir ekstra problematisk når fenomenene beskrives som utpreget onde og det tas $\mathrm{i}$ bruk og legitimerer metoder som ellers oppfattes som lite ønskelig i demokratiske samfunn.

3 SWIFT, Fedwire og lignende systemer har medført at det daglig flyttes enorme summer. For 10 år siden var man allerede oppe i over 700000 transaksjoner daglig internasjonalt med ca 2000 milliarder dollar daglig som ble flyttet (UN ODCCP 1998). Dette er småtteri mot dagens aktivitet.

$4 \quad$ Sikkerhet er en vekstbransje, enhver som betviler dette bør besøke den årlige messen i Birmingham som er Europas største. Det er bokstaveligtalt flere tusen utstillere som selger alt fra brannslukningsutstyr til iris scanere og overvåkningsutstyr. Det arrangeres også egne undervisningstilbud på høyskolenivå blant annet av BI innen sikkerhet.

5 Skjemaet ble forelagt respondenter som ellers var positive til undersøkelsen, men ble ikke besvart, selv etter flere kontakter. En grunn kan nok være at det ble oppfattet som relativt arbeidskrevende å besvare disse spørsmålene i Norge, når man ikke hadde en like klar oppfatning om de ulike kostnadene som i Sverige.

6 I Norge går dette ikke til Kredittilsynet, men til Økokrim. I Norge skjer dette elektronisk gjennom systemet AltInn.

7 I Sverige benevnes forretningsbanker med termen bankaksjeselskap.

$8 \quad$ På engelsk benevnes primærforbrytelsene som predicative offences. Reuter og Truman (2004) deler disse primærforbrytelsene i fem kategorier, det er: narkotikasmugling, andre former for tradisjonell kriminalitet, økonomisk kriminalitet, korrupsjon / smøring og terror.

$9 \quad$ Her føler Larsson et visst ansvar, i sin tid som leder av seksjonen for analyse og forebygging i Politidirektoratet fremhevet han stadig den etterretningsmessige verdien som kunne ligge i meldingene.

10 DnBNor utvikler sitt eget overvåkningssystem som har en kostnadsramme på ca. 150 millioner kroner. Mens EDB businesspartner sitt opplegg blir betydelig billigere med en utviklingskostnad på $10-15$ millioner.

Adresse:

Paul Larsson

Politihøgskolen

Slemdalsveien 5, 0369 Oslo. paul.larsson@phs.no

\author{
Dan Magnusson \\ Internationella \\ Handelshögskolan i Jönköping \\ Box 1026 \\ SE-551 11 Jönköping \\ dan.71130linde@spray.se
}

